\title{
Should Codification Emerge in IFRS? Does Form of Regulation Matter?
}

\section{György Andor and Ildikó Rózsa}

Budapest University of Technology and Economics (BME), Department of Finance, Magyar tudósok körútja 2, H-1117 Budapest, Hungary, rozsa@finance.bme.hu; andor@finance.bme.hu

\begin{abstract}
The International Financial Reporting Standards (IFRS) is in the process of becoming globally recognised in stock exchanges alongside the Generally Accepted Accounting Principles in the United States (US GAAP). The IFRS and US GAAP have evolved based on the GAAP encompassed by the list of standards that constitute the structure of both accounting literatures. The structure that this article refers to as "standard-based" has been a traditional format for the IFRS and US GAAP in the past. Whereas the IFRS still maintains a standard-based literature structure, US GAAP standard setters of the Financial Accounting Standards Board (FASB) decided to depart from the standard-based tradition of editing accounting literature by redesigning the existing authoritative US GAAP literature into a single codified text, titled the Accounting Standards Codification (ASC). This paper focused on the structures of IFRS and US GAAP to understand whether the ASC enhances the application of US GAAP by professionals. The objective of this paper was to determine whether the structure of the ASC offers an appropriate alternative to the standard-based structure of IFRS - making IFRS a userfriendly accounting literature in Central Europe. We administered a survey as a tool to foster discussion and to identify the features offered by the ASC, which is similar in structure to statutory accounting traditionally adopted in Central Europe.
\end{abstract}

Keywords: IFRS; US GAAP; Codification; standard-based structure; stock exchange

\section{Introduction}

The International Financial Reporting Standards (IFRS) and the Generally Accepted Accounting Principles in the United States (US GAAP) have played a significant role in improving financial reporting information on an international scale. The International Accounting Standards Board (IASB) and the Financial Accounting Standards Board (FASB), which are the standard setters of the IFRS and US GAAP, respectively, have made important efforts to converge the respective accounting literatures with the objective of reducing the existing differences between the IFRS and US GAAP. As part of this convergence endeavour, the IFRS has gradually achieved global recognition along with the US GAAP. For example, approximately 120 countries encourage or require the 
application of the IFRS. Other countries have adopted the IFRS by drafting local accounting legislation in line with IFRS, resulting in further acceptance of the IASB by the international community [2]. In particular, the European Union has imposed the application of the IFRS by public companies.

This progress provides an exciting opportunity to compare recent developments in the way the IFRS and US GAAP are being communicated to the public. Both the IFRS and US GAAP have evolved based on generally accepted accounting principles embodied in thoroughly documented conceptual statements that provide solid ground in developing accounting standards. The standard-based approach to accounting is common and traditional to the IFRS and US GAAP. Under a standard-based approach, the structure of the accounting literature refers to the chronological sequence of standards issued over time. The reference numbers of the standards do not particularly refer to the sequence of financial statement components or name any particular financial statement components. For example, intangible assets are listed among the first lines in the balance sheet, whereas the reference number of the relevant standard is IAS 38. Additionally, the standard titled "Construction contracts" does not refer to any particular financial statement line item. Some countries in Europe apply standard-based accounting principles, for example, the UK, where the structure of the accounting literature is very similar to that of the IFRS or US GAAP prior to codification (see section 2 for more information about the Accounting Standards Codification). In most of Europe, however, accounting is subject to legislation, where accounting conventions are driven by statute and enacted by law. The structure of legislative accounting literature has a different approach to the documentation of accounting rules. If the IFRS and US GAAP can be considered "standard-based", then legislative accounting documentation can be referred to as being "analog" instead. In Hungary, for example, accounting law holds that the rules be listed in a sequence consistent with the sequence of financial statement line items as they appear on balance sheets and income statements. That is, if intangible assets appear in line 1 of a balance sheet, then the first paragraph will refer to the accounting treatment of intangibles in the section regarding balance sheet regulations.

Because of the differences experienced in the way standard-based and legislative accounting structures are designed, most European entities encounter severe difficulties in applying the IFRS or US GAAP prior to codification. Professionals who are not confident in handling standard-based accounting structures will need further knowledge to perform advanced searches of the IFRS or US GAAP to find answers to particular accounting issues. The extensive cross-referencing between accounting standards create further difficulties for professionals used to the legislative structure in ensuring whether all items in a subject are adequately covered when performing a search of the IFRS or US GAAP prior to codification. As a result, experience shows that as requirements to adopt the IFRS have become more widespread in Europe, significant resistance has been triggered at the same time by entities in countries where accounting rules adopt a legislative structure. 
The analog structures of accounting legislation in most European countries provide a lean approach to obtaining a comprehensive overview of accounting regulation. In addition to the structural differences experienced in standard-based accounting literatures, the language and the approach used have made companies reluctant to adopt the IFRS. In the paper, we considered the difficulties that most countries in Europe encounter in the process of becoming familiar with the standard-based approach to accounting structure with the introduction of the IFRS.

In the course of events, the FASB implemented a substantive change in the structure of the US GAAP with the objective of gathering all relevant existing GAAP literatures into a uniform structure, known today as the Accounting Standards Codification (or the Codification). Because the new structure of the Codification (discussed in section 2) agrees with the analog approach of most legislative accounting structures, the Codification inspired us to challenge the existing structure of the IFRS. The purpose of this paper was to examine the implications of the Codification to understand whether users enjoy the benefits of the new US GAAP structure and determine whether users would welcome a similar change to the IFRS structure.

\section{The Development of Accounting standards Codification}

\subsection{Accounting Standards Codification}

The US GAAP authoritative literature includes a large number of publications issued over the past fifty years by various professional bodies. The publications, including standards, interpretations, position statements, and opinions, have been published in a relatively uncoordinated manner. Each professional body has applied a unique method for coding the publications, which are very much inconsistent from one another. By 2009, the literature comprised over 2,000 publications. The large amount of literature maintained under relative disintegration could not facilitate efficient research based on the publications. The FASB alone issued 168 standards, accompanied by further publications adding to the total. In addition, the standards themselves had features similar to those of the IFRS, such as extensive cross-references between standards; the coverage of a single topic by more than one standard; and a sequential numbering of standards based on chronological order rather than any order of financial statement components. As a result, criticism began to focus on the lack of a consistent and concise approach inherent to the standard-based US GAAP structure. Professional bodies believed that the US GAAP structure was unwieldy and difficult to follow [11]. Criticism also noted risks associated with the structure, such as the possible incompleteness of research work given the wide range of relevant publications available for review. Consequently, the existing standard-based structure was 
discouraging to professionals in maintaining timely knowledge in a cost-effective manner. In response, the FASB took action and announced its project to target the weaknesses identified above.

To initiate the project, the FASB first surveyed the opinions of users of the US GAAP through questionnaires. Companies and practicing professionals were invited to the survey, representing a total of 1,400 participants who received questionnaires featuring the following questions [8]:

Q-1: Do you find the current US GAAP literature confusing?

Q-2: Does research in the current system require considerable time?

Q-3: Would codification make the system more understandable?

Q-4: In your opinion, will codification make searching in the system easier?

Q-5: In your opinion, should FASB pursue codification?

The results of the survey were favourable, and the Accounting Standards Codification (ASC or, Codification) project was launched with over 200 professionals from different entities being involved. The Codification structure intended to differ significantly from the existing standard-based US GAAP structure. The objective of the Codification project was to facilitate access to the complete authoritative US GAAP literature. The Codification did not change existing accounting principles but rearranged the existing and relevant publications into a user-friendly structure to facilitate consistency and completeness in accounting research. Ultimately, the existing authoritative literature was organised under approximately 90 different topics, each dedicated to separate areas of concentration, such as assets, liabilities, equity, expenses, and revenue accounts in financial statements. In this context, it is important to underline that the FASB moved toward a structure that was much different from what was previously known as a standard-based structure.

The Accounting Standards Codification was effective on June 30, 2009 as the single authoritative US GAAP literature, and former publications were no longer authoritative subsequent to that date. Review and update processes take place within the Codification platform on an annual basis. Any change or revision is documented and announced in the Accounting Standards Updates (ASU), which is the exclusive forum used to communicate amendments to the Codification.

\subsection{Experience in Europe after Inception of Accounting Standards Codification}

We reviewed the results of the FASB survey three years after the Codification was implemented. We were interested in determining whether the Codification provided effective solutions to previous difficulties and whether the properties of the former standard-based structure still remain. We reissued the initial survey to compare how users feel about the Codification three years after. We invited 100 
US GAAP users, including practicing professionals with considerable experience, from several European countries: Austria, Bulgaria, the Czech Republic, France, Germany, Hungary, Poland, Romania, Slovakia, Slovenia, and Spain.

The sample was composed of 100 individual European entities that are subsidiary undertakings of companies headquartered and listed in the United States. The companies under survey are, therefore, continuously involved in the preparation of quarterly and annual financial reporting in compliance with SEC requirements. Such requirements include the filing of form 10-Q and 10-K reports quarterly and at year end, respectively. In a group structure, subsidiaries deliver the quarterly and annual reports to the headquarters for consolidation purposes at the group level. In the sample, we avoided selecting foreign security issuers and overseas companies that are directly listed in the US because such companies are subject to annual reporting only. The SEC requires foreign companies to submit form $20-\mathrm{F}$ once at year end, and it may be prepared in accordance with the IFRS. Since 2008, the SEC has no longer required foreign companies to reconcile their local financial statements to US GAAP accounts. Foreign companies, therefore, would not have been representative of the sample because such companies exhibit limited use of the US GAAP.

We achieved a 74 percent survey response rate, i.e., 74 questionnaires out of 100 were accepted as complete for evaluation purposes. The number of responses by country were as follows: 7 from Austria, 9 from Bulgaria, 8 from the Czech Republic, 5 from France, 11 from Germany, 16 from Hungary, 8 from Poland, 4 from Romania, 2 from Slovakia, 1 from Slovenia, and 3 from Spain.

The questions we designed for our survey were based on the questions initially posed by the FASB:

Q-1: Do you find the current US GAAP literature confusing?

Q-2: Does research in the current system require considerable time?

Q-3: In your opinion, has the Codification made the literature more understandable?

Q-4: In your opinion, has the Codification made research in the literature easier?

Q-5: In your opinion, was the Codification worth launching?

Table 1 compares the results of our survey with those of the previous FASB survey conducted in 2008. 
Table 1

Survey of demand for US GAAP codification (by FASB; N=1400; source: Finance Accounting Foundation 2008) and experiences with US GAAP codification $(\mathrm{N}=74)$

\begin{tabular}{|l|c|c|}
\hline & $\begin{array}{c}\text { Survey } \\
(\mathbf{2 0 0 8})\end{array}$ & $\begin{array}{c}\text { Survey } \\
(\mathbf{2 0 1 2})\end{array}$ \\
\hline $\begin{array}{l}\text { Believe the current system of US GAAP regulation is } \\
\text { confusing }\end{array}$ & $80 \%$ & $31 \%$ \\
\hline $\begin{array}{l}\text { Believe searching the current system requires } \\
\text { considerable time }\end{array}$ & $85 \%$ & $38 \%$ \\
\hline $\begin{array}{l}\text { Believe codification makes / has made the US GAAP } \\
\text { more understandable }\end{array}$ & $87 \%$ & $81 \%$ \\
\hline $\begin{array}{l}\text { Believe codification will make / has made searching in } \\
\text { the system easier }\end{array}$ & $96 \%$ & $79 \%$ \\
\hline Believe it would be / was worth launching codification & $95 \%$ & $82 \%$ \\
\hline
\end{tabular}

It should be noted that the population surveyed by the FASB was different from the population we surveyed, and the sample we selected was not statistical. Nevertheless, the sampling technique was sufficient to understand whether users welcomed the Codification overall. It appears that Europeans working in legislative accounting environments could identify with the structure outlined in the Codification because of its direct relationship to financial statement accounts represented by areas of concentration, as mentioned earlier. The survey results indicate that the Codification made the US GAAP transparent and clear to follow for European users.

\section{Demand for IFRS Codification in Europe}

\subsection{Existing IFRS Structure}

The following section will focus on the existing structure and properties that characterise the IFRS as the other significant representative of accounting literature on a global level along with the US GAAP. The IFRS includes three authoritative texts: the Framework, Standards, and Interpretations. Readers of the IFRS must continuously consider the interrelations between standards and interpretations that cover a number of accounting topics that reference one another across different standards and interpretations.

In an effort to globalise the IFRS, the IASB amended or superseded a number of standards and issued new standards in recent years. In addition, the IASB is looking forward to issuing further standards in the future. Nevertheless, the IFRS literature included fewer publications than the US GAAP prior to the codification due to the history and organisational background of the IASB. The IASB is a younger organisation than the FASB and its surrounding organisations but is also the ultimate body governing the IFRS. In contrast, various professional bodies 
contributed to the US GAAP, leading to a number of different publications before the codification. In this context, we discovered opinions indicating that the IFRS is currently in a stage where the US GAAP was 30 years ago in terms of exhibiting a standard-based structure. Even if there are fewer IFRS publications than pre-codified US GAAP publications, the existing structure of the IFRS is alien to users working in legislative accounting environments. The extensive cross-references between standards and specific editing matters make the IFRS difficult to oversee. Additionally, the numbering of IFRS publications is based on chronological order rather than any particular sequence of financial statement components, similarly to the US GAAP prior to codification. In light of the existing IFRS structure, which shares much in common with the pre-codified US GAAP, it may be worth considering whether the codification of the IFRS would lead to favourable results similar to those observed for the codification of the US GAAP.

Table 2 presents a summary of the cross-references between standards effective on January 1, 2012. The table indicates that the standard number of cross-references is 6 on average. Common or mandatory standards such as IAS 1, IAS 12, and IAS 16 indicate a greater number of cross-references, whereas industry-specific standards such as IAS 29 and IFRS 6 indicate fewer cross-references relative to the average. From a statistical point of view, the standard deviation of references from one particular standard towards other standards is 6.13 , whereas the standard deviation of references towards one particular standard from other standards is 3.84. Considering solely cross-references between standards and omitting other references to interpretations and limitations in scope, the total number of crossreferences is 6 on average based on the number of effective standards in place.

Table 2

Relationships among IFRS standards (Only includes standards in force as of January 1, 2012)

\begin{tabular}{|c|c|c|c|c|c|c|c|}
\hline Standard & $\begin{array}{c}\text { Its refe- } \\
\text { rences }\end{array}$ & $\begin{array}{c}\text { References } \\
\text { to it }\end{array}$ & $\begin{array}{c}\text { Ex- } \\
\text { ceptions }\end{array}$ & Standard & $\begin{array}{c}\text { Its refe- } \\
\text { rences }\end{array}$ & $\begin{array}{c}\text { References } \\
\text { to it }\end{array}$ & $\begin{array}{c}\text { Ex- } \\
\text { ceptions }\end{array}$ \\
\hline IAS 1 & 36 & 12 & 1 & IAS 31 & 4 & 3 & 3 \\
\hline IAS 2 & 2 & 6 & 3 & IAS 32 & 6 & 10 & 6 \\
\hline IAS 7 & 2 & 3 & - & IAS 33 & 6 & 2 & - \\
\hline IAS 8 & 7 & 14 & 1 & IAS 34 & 4 & 1 & - \\
\hline IAS 10 & 8 & 4 & - & IAS 36 & 5 & 12 & 9 \\
\hline IAS 11 & 2 & 3 & - & IAS 37 & 4 & 14 & 8 \\
\hline IAS 12 & 10 & 6 & 1 & IAS 38 & 10 & 9 & 13 \\
\hline IAS 16 & 10 & 11 & 5 & IAS 39 & 6 & 10 & 10 \\
\hline IAS 17 & 7 & 6 & 3 & IAS 40 & 10 & 4 & 1 \\
\hline IAS 18 & 2 & 5 & 7 & IAS 41 & 7 & 4 & 4 \\
\hline IAS 19 & 4 & 7 & 2 & IFRS 1 & 14 & 1 & 1 \\
\hline IAS 20 & 2 & 5 & 2 & IFRS 2 & 1 & 5 & 4 \\
\hline IAS 21 & 5 & 9 & 3 & IFRS 3 & 13 & 10 & 1 \\
\hline IAS 23 & 1 & 4 & 2 & IFRS 4 & 8 & 2 & 11 \\
\hline
\end{tabular}




\begin{tabular}{|c|c|c|c|c|c|c|c|}
\hline IAS 24 & 1 & 4 & - & IFRS 5 & 4 & 12 & 6 \\
\hline IAS 26 & - & 2 & 2 & IFRS 6 & 6 & 2 & - \\
\hline IAS 27 & 4 & 7 & 1 & IFRS 7 & 4 & 3 & 7 \\
\hline IAS 28 & 5 & 4 & 1 & IFRS 8 & 2 & 6 & - \\
\hline IAS 29 & 1 & 1 & - & & & & \\
\hline Subtotal & 109 & 113 & 34 & & 114 & 110 & 83 \\
\hline Total & & & & & 223 & 223 & 117 \\
\hline Average & & & & & 6 & 6 & 3 \\
\hline $\begin{array}{l}\text { Standard } \\
\text { deviation }\end{array}$ & & & & & 6,13 & 3,84 & 3,52 \\
\hline
\end{tabular}

Table 3 illustrates the complexity of cross-references in a network of interrelations between standards. The network excludes cross-references between interpretations and limitations in scope for simplicity. Still, the diagram indicates that the network of interrelations between standards is extensive and topics are difficult to follow. The chart shows a positive correlation between standards only. It is clear that the number of references between standards is significant, and to study a topic requires comprehensive knowledge of all standards.

The continuous revisions of existing standards and issuances of new standards may further complicate the IFRS literature in future. Under these conditions, the opportunity to evaluate the viability of a possible codification of the IFRS has been welcome. Codification efforts should therefore commence in due course to implement a structure that provides a user-friendly approach to readers of the IFRS.

\subsection{IFRS Presence in Europe}

The extent to which the IFRS is applied in Europe varies by country. In some European countries, the application of the IFRS is optional under certain conditions. For example, in Hungary, companies may opt to use the IFRS in preparing consolidated financial statements. Additionally, the mandatory use of the IFRS may vary by industry sector. For example, financial institutions must issue annual consolidated financial statements in compliance with the IFRS. Private companies are free to use the IFRS, whereas publicly listed companies in the European Union must report under the IFRS on a consolidated basis [18]. Because local accounting regulations are mandatory by statute, businesses within the scope of the IFRS must comply with both accounting requirements in turn. Additionally, there are certain countries where the IFRS has replaced local accounting legislations in a specific manner. Such inconsistent expectations regarding when and how the IFRS should be applied makes financial reporting difficult to compare between industries [10]. 
Table 3

Links and references between standards

IAS 1 IAS2 IAS7 IAS 8 IAS 10 IAS 11 IAS 12 IAS 16 IAS 17 IAS 18 IAS 19 IAS 20 IAS21 IAS 23 IAS 24 IAS 26 IAS 27 IAS 28 IAS 29 IAS 31 IAS 32 IAS 33 IAS 34 IAS 36 IAS 37 IAS 38 IAS 39 IAS 40 IAS 41 IFRS 1 IFRS 2 IFRS 3 IFRS 4 IFRS5 IFRS 6 IFRS 7 IFRS 8 IAS 1 -

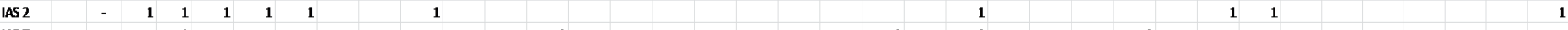

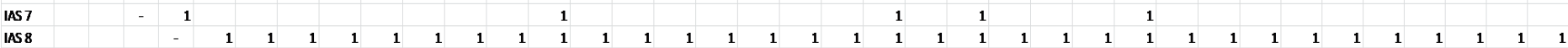

IAS 10

IAS 10

IAS 11
IAS 12
IAS 16
IAS 17

\begin{tabular}{l} 
IAS 16 \\
IAS 17 \\
IAS 18 \\
\hline IAS 19
\end{tabular}

IAS 18
IAS 19
IAS 20

IAS 20

iAs 21

IAS 23
IAS 24
IAS 26
IAS 27

IAS 26

IAS 27

IAS 28

IAS 29

AS 31

IAS 32
IAS 33
IAS 34

IAS 34
IAS 36

IAS 37

IAS 38

IAS 38
IAS 39

IAS 39

IAS 40

AS 41

IFRs 1

(1)

IFS

IFRS4

IFRS 5

IFRS6

IFRS7
IFRS8

$$
\text { IFRS8 }
$$

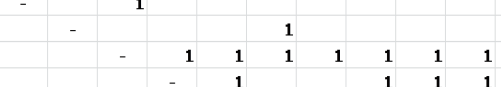


Table 4

Summary of use of IFRS in some European countries [4]

\begin{tabular}{|c|c|c|c|c|c|c|c|c|c|c|}
\hline & Austria & Bulgaria & $\begin{array}{c}\text { Czech } \\
\text { Republic }\end{array}$ & France & Germany & Hungary & Poland & Romania & Slovakia & Slovenia \\
\hline $\begin{array}{l}\text { Is the use of IFRS } \\
\text { obligatory in } \\
\text { standalone statements? }\end{array}$ & No & $\begin{array}{c}\text { Yes } \\
\text { (except } \\
\text { for SME- } \\
\text { s) } \\
\end{array}$ & No & No & No & No & No & No & $\mathrm{No}^{\text {a) }}$ & $\mathrm{No}^{\text {b) }}$ \\
\hline $\begin{array}{l}\text { Is the use of IFRS } \\
\text { obligatory in } \\
\text { consolidated } \\
\text { statements? }\end{array}$ & No & $\begin{array}{c}\text { Yes } \\
\text { (except } \\
\text { for SME- } \\
\text { s) }\end{array}$ & No & No & No & No & $\mathrm{No}^{\mathrm{c}}$ & $\mathrm{No}^{\mathrm{c})}$ & Yes & $\mathrm{No}^{\mathrm{b})}$ \\
\hline $\begin{array}{l}\text { Can the use of IFRS be } \\
\text { chosen for standalone } \\
\text { statements? }\end{array}$ & No & Yes & No & No & No & No & $\mathrm{No}^{\mathrm{d})}$ & No & No & Yes ${ }^{e}$ \\
\hline $\begin{array}{l}\text { Can the use of IFRS be } \\
\text { chosen for } \\
\text { consolidated } \\
\text { statements? }\end{array}$ & Yes & Yes & Yes & Yes & Yes & Yes & $\mathrm{No}^{\mathrm{d})}$ & Yes & No & Yes ${ }^{e}$ \\
\hline $\begin{array}{l}\text { Do they use statutory } \\
\text { accounting regulation } \\
\text { or standards? }\end{array}$ & $\begin{array}{l}\text { Statutory } \\
\text { regulation } \\
f \mathrm{f}\end{array}$ & $\begin{array}{l}\text { Statutory } \\
\text { regulation } \\
\mathrm{g})\end{array}$ & $\begin{array}{l}\text { Statutory } \\
\text { regulation } \\
\text { h) }\end{array}$ & $\begin{array}{l}\text { Statutory } \\
\text { regulation } \\
\text { p) }\end{array}$ & $\begin{array}{l}\text { Statutory } \\
\text { regulation } \\
\text { (trends on } \\
\text { standard- } \\
\text { based }\end{array}$ & $\begin{array}{l}\text { Statutory } \\
\text { regulation }\end{array}$ & $\begin{array}{l}\text { Statutory } \\
\text { regulation }{ }^{\mathrm{j})}\end{array}$ & $\begin{array}{l}\text { Statutory } \\
\text { regulation }{ }^{\mathrm{k})}\end{array}$ & $\begin{array}{l}\text { Statutory } \\
\text { regulation }\end{array}$ & Standards ${ }^{\mathrm{m})}$ \\
\hline \multicolumn{11}{|c|}{$\begin{array}{l}\text { a)Except for financial institutions, insurance companies, asset managers, and large enterprises (which exceed } 2 \\
\text { from } 3 \text { indicators in two successive years: assets of } 150 \text { million EUR, annual revenue of } 150 \text { million EUR, and a } \\
\text { staff size of 2000); b) Except for financial institutions and insurance companies; c) Except for financial } \\
\text { institutions; d) Except for companies listed on the stock market and companies with a parent company abroad; e) } \\
\text { Yes, but the domestic accounting report cannot be chosen for } 5 \text { years after decision; f) Austrian Commercial } \\
\text { Code (UGB); g) SG 4/15.01.1991, but already standards today; h) Accounting Directives Law (Act No. } \\
563 / 1991 \text { ); i) Hungarian Accounting Law (Act No. C); j) Act of } 29 \text { September } 1994 \text { on Accounting (“AA”); k) } \\
\text { Accountancy Law No.82/1991; 1) Accounting Act No. } 431 / 2002 \text {. as amended by Act no. 562/2003 Coll. and Act } \\
\text { no. 561/2004 Coll.; m) Slovenian Accounting Standards, Source: (IFRS Foundation, 2011); o) } \\
\text { Bilanzrechtsmodernisierungsgesetz (German Act on the Modernisation of Accounting Law), p) Plan Comptable } \\
\text { Général (PCG) }\end{array}$} \\
\hline
\end{tabular}


From the survey, we highlight the case in Slovenia and Bulgaria, where the IFRS has been imposed for all types of financial statements, including stand-alone statements of private companies. We paid special attention to Bulgaria to study the effects of IFRS application. Despite the fact that the IFRS superseded the former accounting law in Bulgaria, resulting in the general requirement of the IFRS in financial reporting, there has been criticism regarding the completeness and consistency of IFRS application in Bulgaria. In 2008, the World Bank reported that Bulgaria has in fact not adapted the IFRS in its complete form. World Bank analyses indicate that there were significant inconsistencies regarding the scope of IFRS application in Bulgaria compared to the scope of EU adoption. The World Bank reviewed 15 company reports and revealed 9 companies whose consolidated financial statements were not in compliance with the IFRS in full. The conclusion drawn by the World Bank required Bulgaria to extend the scope of the IFRS in local accounting regulations [19].

The overall results of our survey with respect to IFRS presence in Europe indicate in Table 4 that financial reporting in most countries is still subject to statutory legislation.

\subsection{Survey of the Demand for IFRS Codification}

To assess the viability of IFRS codification, a survey similar to that initiated by the FASB prior to the codification of the US GAAP should be administered to IFRS users as well. As a start, we submitted 300 questionnaires to practicing professionals in different multinational companies, of which 218 responses were received, representing a $73 \%$ response rate. Not all responses were complete; incomplete responses were considered inadequate for processing. We considered 194 responses appropriate for evaluation. The questionnaire addressed the following questions, which are consistent with the questions designed by the FASB in preparation of the ASC project:

Q-1: Do you find the current IFRS literature confusing?

Q-2: Does research in the current IFRS require considerable time?

Q-3: Would IFRS codification make the system more understandable?

Q-4: In your opinion, will IFRS codification make searching the system easier?

Q-5: In your opinion, should the IASB pursue IFRS codification?

\subsubsection{Sample Selected}

For the sample, we selected multinational companies because of the predominant use of the IFRS in this sector in Europe due to public listings or foreign ownerships. Table 5 is a summary of the 194 companies evaluated in the survey, by sector; the number of companies publicly listed is indicated in a separate column. We considered it important to include publicly listed companies in the survey sample as well because such companies must prepare financial statements under the IFRS. 


\subsubsection{Evaluation of the Survey}

Responses to the five questions listed above are summarised in Table 6. The results indicate that the codification of IFRS might be a possible alternative to the current system.

Table 5

Number of respondents and listed companies by sector

\begin{tabular}{|l|c|c|}
\hline \multicolumn{1}{|c|}{ Sector } & Number of responses & $\begin{array}{c}\text { Listed on stock } \\
\text { exchange }\end{array}$ \\
\hline Energy and services & 31 & 18 \\
\hline Building industry & 18 & 11 \\
\hline Automobile industry & 29 & 20 \\
\hline Telecommunication & 18 & 18 \\
\hline Pharmaceutical industry & 19 & 17 \\
\hline Media & 7 & 4 \\
\hline Merchandising & 28 & 13 \\
\hline Transportation and delivery & 15 & 10 \\
\hline Bank and insurance & 29 & 29 \\
\hline Total & $\mathbf{1 9 4}$ & $\mathbf{1 4 0}$ \\
\hline
\end{tabular}

Table 6

Survey of demand for US GAAP codification (by FASB; N=1400; source: FASB 2008) and demand for IFRS codification $(\mathrm{N}=194)$

\begin{tabular}{|l|c|c|}
\hline & $\begin{array}{c}\text { US GAAP } \\
\mathbf{( 2 0 0 8 )}\end{array}$ & $\begin{array}{c}\text { IFRS } \\
\mathbf{( 2 0 1 2})\end{array}$ \\
\hline $\begin{array}{l}\text { Believe the system of the US GAAP / the IFRS regulation is } \\
\text { confusing }\end{array}$ & $80 \%$ & $39 \%$ \\
\hline Believe searching the current system requires considerable time & $85 \%$ & $73 \%$ \\
\hline $\begin{array}{l}\text { Believe codification would make the US GAAP / the IFRS } \\
\text { more understandable }\end{array}$ & $87 \%$ & $69 \%$ \\
\hline Believe codification will make searching in the system easier & $96 \%$ & $71 \%$ \\
\hline Believe it would be worth launching codification & $95 \%$ & $77 \%$ \\
\hline
\end{tabular}

To draw a fair conclusion from the results of the survey, we identified the following three factors for consideration.

First, it is important to note that the sample surveyed regarding IFRS codification consisted users unlike those initially surveyed by the FASB with respect to US GAAP codification. Although both groups of users are involved in accounting, the environment in which they practice and the challenges they encounter are inherently different. The background and structure of the US GAAP before codification and the existing IFRS literature exhibit different features (see sections 2.1 and 3.1), which may have affected the ways in which the participants in the two groups interpreted the questions in the surveys. 
The second factor considered is the sizes of the samples selected by the FASB and by us for the purpose of this paper. The FASB survey results were gathered from 1,400 questionnaires, as opposed to the results of our survey, which were gathered from 300 questionnaires. We acknowledge that the scope of our survey may appear limited compared with the scope of the FASB survey. To compensate for any possible adverse effects the relative sample size may have had on the results, we focused on the composition of the companies invited to the survey (Table 5). We expected that the variety of sectors presented in our sample would, to a favourable extent, offset the shortcomings attributable to the sample size.

Third, the different approaches applied in carrying out the surveys may have also caused deviations in interpreting the percentages presented in Table 6 . The results of the US GAAP survey were used in this paper as readily available source of data. We had no background details available regarding the methodology applied by the FASB in deriving the results of its survey. Therefore, we cannot conclude whether our approach for evaluating the results of our survey was in any way identical to that employed by the FASB. In our approach, we asked the participants to answer the questions on a scale of 10, where 1 represented the lowest satisfaction and 10 the highest satisfaction in response to the questions. We then calculated the average score of the responses and weighted the average based on the scale. Finally, we related the weighted averages to the total number of responses received, by question, to calculate the percentages. The percentages, therefore, are considered to represent the relative expectations and attitudes of the participants towards the five issues addressed by the questions.

The evaluation of the survey results is sensitive to the factors described above. The results derived from our survey are affirmative to the extent that we acknowledge possible differences between the features of the two groups of samples; the way they have been selected; and the approach used to evaluate the responses gathered from the participants. Although the percentages regarding the demand for IFRS codification seem less promising than those indicated by the FASB survey, our results remain above marginal, indicating that IFRS codification may be a timely proposal for a certain group of professionals. However, regarding the question whether the codification of the IFRS would represent an important contribution to the profession, we considered further conditions, as discussed in Section 3.4.

\subsection{Further Considerations Regarding IFRS in Europe}

The objective of this section is to consider others factors that explain why most countries in Europe may be unwilling to adopt the IFRS in its existing form unless codification of the IFRS literature takes place.

Previous assessments mentioned in this article indicate that traditionally accounting is subject to statutory legislation in most of Europe, where users are 
familiar with the content of accounting laws and favour the customary approach to structuring rules and regulations. Today, the Accounting Standards Codification in the United States shares many aspects in common with legislations favoured in Europe in terms of structuring accounting literature. The ASC proposed a consistent approach to editing and updating accounting requirements oriented toward areas of concentration, including individual financial statement components - a very similar approach observed in legislative environments in Europe. In contrast to the ASC, the IFRS structure is driven by a list of standards that do not accommodate users in legislative environments to conduct research easily.

In most European countries, entities must comply with charts of accounts predefined in local accounting legislations. The IFRS, in turn, does not outline such distinct procedures [15]. If local legislations were to remove mandatory requirements similarly to the chart of accounts, then practicing professionals would lose reference and comfort in the application [17].

Despite the successful distribution of IFRS publications, the IFRS has been released in a limited number of languages. As a consequence, a number of studies have concluded that the lack of available languages in which the IFRS is published [14] and the lack of timely revisions of IFRS publications issued in languages other than English make it difficult for users to follow the relevant literature [1] [7].

Because statutory accounting rules are often driven by taxation, some countries in Europe oppose the introduction of the IFRS overall [5] [6] [10] [12] [13] [16]. Others have observed that the different national tax regimes represent the primary obstacles to imposing the IFRS in local accounting environments [9].

Continuing professional development is another area of controversy [3]. Professional IFRS training courses vary in timing and quality by country. Because IFRS knowledge is not a prerequisite to obtaining local accounting certificates, candidates do not appreciate such courses.

Having reviewed the structures of the ASC and IFRS, as well as the characteristics of local legislations, we believe that the structures attributable to national accounting legislations have conceptually more in common with the Codification than with the standard-based IFRS. Therefore, we anticipate that the structure of the Codification is a suitable reference to use for the possible codification of the IFRS. In the following section, we discuss a possible alternative to IFRS codification based on the existing ASC structure. 


\section{Possible Way to Codify IFRS}

Following our discussions with respect to the difficulties users encounter in applying the IFRS in Europe, in this section, we encourage the initiative to rearrange the IFRS to overcome this obstacle. The primary difficulty with the existing structure of the IFRS is that many practicing professionals in Europe find it unusual compared to the structures followed by local legislations. Therefore, we recommend a structure very similar to what was developed under the ASC in the United States. The codification approach should lead to a structure with which users will be able to more easily identify, in contrast to any possible revised versions of the standard-based approach to the IFRS.

Having observed the codification process in the United States, we are convinced that traditional standard-based structures are not necessarily practical in the long term. Therefore, the time to initiate the codification of the IFRS may well be now. We expect the codified structure to ease the review of standards and the monitoring of amendments to standards in the IFRS literature. Additionally, we expect that the large number of IFRS opponents will be assuaged once a codified structure replaces the existing standard-based structure. Certainly, a codification of the IFRS will not overcome the conflict with the various taxation regimes in Europe governing local accounting rules. To date, taxation has been considered one of the strongest arguments against IFRS introduction. In evaluating the merits and possible demerits of IFRS codification, we propose to carry forward and initiate a codification structure based on the ASC implemented in the United States. That is, all standards and interpretations effective to date will be rearranged into a new codified structure to enable readers to follow IFRS literature in a userfriendly form. Finally, the codified IFRS should represent the sole authoritative reference for practicing professionals.

Table 7 demonstrates the way IFRS can be codified.

\section{Conclusions}

Today's accounting environment is in an inevitable result of globalisation. The standard setters of the IFRS and US GAAP have significant influence over financial reporting requirements at the international level. Current trends indicate that the IFRS will take a leading position in global accounting in the near future. The developments in this area inspired us to investigate and examine the merits and possible demerits of, as well as the arguments for and against, the IFRS. We focused primarily on the differences between the ways in which the IFRS and US GAAP are structured, rather than discussing differences in accounting conventions that have already converged in recent years. Briefly, we challenged the current standard-based structure of the IFRS using the well-received Codification in the United States. 
Table 7

Draft of a possible IFRS codification based on the US codification structure

\begin{tabular}{|c|c|}
\hline US GAAP codification structure & Classification of IFRS standards \\
\hline General Principles & Framework, IAS 1 \\
\hline \begin{tabular}{l}
\multicolumn{1}{c}{ Presentation } \\
205-Presentation of Financial Statements \\
210-Balance Sheet \\
215-Statement of Shareholder Equity \\
220-Comprehensive Income \\
225-Income Statement \\
230-Statement of Cash Flows \\
235-Notes to Financial Statements \\
250-Accounting Changes and Error Corrections \\
255-Changing Prices \\
260-Earnings per Share \\
270-Interim Reporting \\
275-Risks and Uncertainties \\
280-Segment Reporting
\end{tabular} & $\begin{array}{l}\text { IAS } 1 \text {, IAS } 34 \text {, IFRS } 1 \text {, IFRS } 8 \\
\text { IAS } 1 \\
\text { IAS } 1 \\
\text { IAS } 1 \\
\text { IAS } 1 \\
\text { IAS } 1 \text {, IAS } 7 \\
\text { IAS } 1 \text {, IAS } 34 \\
\text { IAS } 8 \text {, IFRS } 1 \text {, Framework } \\
\text { IAS } 21, \text { IAS } 29 \text {, IFRIC } 7 \text {, SIC } 7 \\
\text { IAS } 33 \text {, IFRS } 2 \\
\text { IAS } 34 \text {, IFRIC } 10 \\
\text { IAS } 8 \text {, IAS } 10, \text { IAS } 37 \\
\text { IFRS } 8\end{array}$ \\
\hline $\begin{array}{l}\text { Assets } \\
\text { 305-Cash and Cash Equivalents } \\
\text { 310-Receivables } \\
\text { 32X-Investments } \\
\text { 330-Inventory } \\
\text { 340-Deferred Costs and Other Assets } \\
\text { 350-Intangibles-Goodwill and Other } \\
\text { 360-Property, Plant and Equipment }\end{array}$ & $\begin{array}{l}\text { IAS } 7 \text {, IAS } 32 \text {, IAS } 39 \text {, IFRS } 7 \\
\text { IAS } 11 \text {, IAS } 18 \text {, IAS } 32 \text {, IAS } 39 \text {, IFRS 7, IFRIC } 13 \text {, SIC } 31 \\
\text { IAS } 27, \text { IAS } 28 \text {, IAS } 31 \text {, IAS } 32 \text {, IAS } 39 \text {, IFRS } 7 \text {, IFRIC } 12 \text {, } \\
\text { IFRIC } 16 \text {, IFRIC } 17 \text {, SIC } 29 \\
\text { IAS } 2 \text {, IAS } 11 \text {, IFRIC } 15 \\
\text { IAS } 23 \text {, IAS } 32 \text {, IAS } 39 \\
\text { IAS } 38 \text {, IFRS } 3 \text {, IFRIC } 12 \text {, SIC } 29 \text {, SIC } 32 \\
\text { IAS } 16 \text {, IAS } 17 \text {, IAS } 20 \text {, IAS } 23 \text {, IAS } 36 \text {, IAS } 40 \text {, IFRS } 5 \text {, } \\
\text { IFRIC } 18\end{array}$ \\
\hline $\begin{array}{l}\text { Liabilities } \\
\text { 405-Liabilites } \\
\text { 410-Asset Retirement and Environmental } \\
\text { Obligations } \\
\text { 420-Exit or Disposal Cost Obligations } \\
\text { 430-Deferred Revenue } \\
\text { 440-Commitments } \\
\text { 450-Contingencies } \\
\text { 460-Guarantees } \\
\text { 470-Debt } \\
\text { 480-Distinguishing Liabilities from Equity }\end{array}$ & 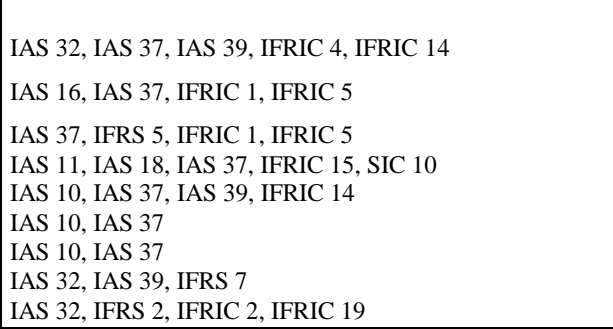 \\
\hline Equity & $\begin{array}{l}\text { IAS 1, IAS 32, IFRS 2, IFRIC 2, IFRIC 16, IFRIC 17, } \\
\text { IFRIC } 19\end{array}$ \\
\hline Revenue & IAS 11, IAS 18, IFRIC 12, IFRIC 13, IFRIC 15, SIC 31 \\
\hline \begin{tabular}{l}
\multicolumn{1}{c}{ Expenses } \\
705-Cost of Sales and Services \\
71X-Compensation \\
720-Other Expenses \\
730-Research and Development \\
740-Income Taxes
\end{tabular} & $\begin{array}{l}\text { IAS } 2 \text {, IAS } 11 \\
\text { IAS } 19 \text {, IFRS } 2 \\
\text { IAS } 16 \text {, IAS } 20 \text {, IAS } 26 \text {, IAS } 36, \text { IAS } 37 \text {, IAS } 39 \text {, SIC } 15 \\
\text { IAS } 38 \\
\text { IAS } 12 \text {, SIC } 21 \text {, SIC } 25\end{array}$ \\
\hline \begin{tabular}{l}
\multicolumn{1}{c}{ Broad Transactions } \\
805-Business Combinations \\
810-Consolidation \\
820-Fair Value Measurements and Disclosures \\
825-Financial Instruments \\
830-Foreign Currency Matters \\
835-Interest \\
840-Leases \\
845-Nonmonetary Transactions \\
\end{tabular} & 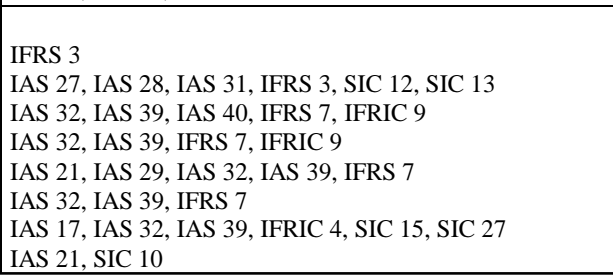 \\
\hline
\end{tabular}


Our results were based on a sample of entities surveyed and analysed through questionnaires. The entities represented operational ASC and IFRS users. From the US GAAP perspective, we analysed the results of the FASB survey initially designed to assess the practical need for codification. Next, we addressed questions, consistent with those previously formulated by the FASB, to a sample of ASC users (post implementation) with the objective of determining the success of codification. Later, we selected a sample of IFRS users to determine whether codification of the IFRS literature would be rational in the future. A considerable number of respondents favoured IFRS codification.

Because users appeared to welcome the idea of IFRS codification, we directly proposed a codified structure of the IFRS similar to the ASC implemented in the United States. Because the ASC has proved to function, we have not considered any further alternative to the future structure of the IFRS other than codification. The proposed method for codification is based on the principles applied in the United States during the ASC project.

The globalisation of financial reporting has been spectacular for the accounting profession. The IFRS is foreseen as becoming a global accounting standard, and listed companies in the United States will be expected to convert financial reporting from the US GAAP to the IFRS. We believe that the codification of the existing IFRS structure may further contribute to its globalisation, as users will most likely be more willing to accept the IFRS literature in a codified structure, which is consistent with ASC or other European legislations, than in its current standard-based format.

\section{References}

[1] Aisbitt, S. and C. Nobes, 2001. The True and Fair View Requirement in Recent National Implementations, Accounting and Business Research, 31(2): 83-90

[2] Choi, F.D.S., C.A. Frost and G.K. Meek, 2002. International Accounting ( $4^{\text {th }}$ ed.), Upper Saddle River, NJ: Prentice Hall, Pearson Education

[3] Christensen, HB, 2012. Why do Firms Rarely Adopt IFRS Voluntarily? Academics Find Significant Benefits and the Costs Appear to be Low. Review of Accounting Studies 17(3): 518-525

[4] Deloitte Global Services Limited, 2010. IAS Plus Implementation of the IAS Regulation (1606/2002) in the EU and EEA, Available at http://www.iasplus.com/europe/1007ias-use-of-options.pdf

[5] Eberhartinger, E. L. E., 1999. The Impact of Tax Rules on Financial Reporting in Germany, France, and the U.K., The International Journal of Accounting, 34(1): 93-119

[6] Eilifsen, A., 1996. The Relationship between Accounting and Taxation in Norway, The European Accounting Review, 5 (Suppl.): 835-844 
[7] Evans, L., 2003. The True and Fair View and the 'Fair Presentation' Override of IAS 1, Accounting and Business Research, 33(4): 311-325

[8] FASB (Finance Accounting Standards Board), 2008. Accounting Standards Codification Notice to Constituents (v1.05), Available at http://asc.fasb.org/imageRoot/10/5724610.pdf

[9] Guenther, D. A. and M. E. A. Hussein, 1995. Accounting Standards and National Tax Laws: The IASC and the Ban on LIFO, Journal of Accounting and Public Policy, 14: 115-141

[10] Haller, A., 2002. Financial Accounting Developments in the European Union: Past Events and Future Prospects, The European Accounting Review. 11(1): 153-190

[11] Herz, R. H., 2003. A Year of Challenge and Change for the FASB, Accounting Horizons, 17(3): 247-255

[12] Holeckova, J., 1996. Relationship between Accounting and Taxation in the Czech Republic, The European Accounting Review, 5 (Suppl.): 859-869

[13] Hoogendoorn, M. N., 1996. Accounting and Taxation in Europe - A Comparative Overview, The European Accounting Review, 5 (Suppl.): 783-794

[14] IFRS Foundation, 2011. Available Translations, Available at http://www.ifrs.org/Use+around+the+world/IFRS+translations/Available+t ranslations.htm

[15] Jaruga, A. A. and A. Szychta, 1997. The Origin and Evolution of Charts of Accounts in Poland, The European Accounting Review, 6(3): 509-526

[16] Lamb, M., C. Nobes and A. Roberts, 1998. International Variations in the Connections Between Tax and Financial Reporting, Accounting and Business Research, 28: 173-188

[17] Nobes, C, 2011. IFRS Practices and the Persistence of Accounting System Classification. Abacus - a Journal of Accounting Finance and Business Studies, 47: 267-283

[18] Street, D.L. and R.K. Larson, 2004. Large Accounting Firms' Survey Reveals Emergence of „Two Standard” System in the European Union, Advances in International Accounting, 17: 1-29

[19] World Bank, 2008. Report on the Observance of Standards and Codes (ROSC) Bulgaria, Available at: http://www.worldbank.org/ifa/rosc_aa_bgr_eng_08.pdf 